\title{
Reka Ulang Waktu Tiba Dan Tinggi Gelombang Tsunami : Studi Kasus Pusat Gempa Di Pantai Utara Bolaang Mongondow
}

\author{
Nismawati Mangiri'a*, Gerald Tamuntuana, Guntur Pasaua \\ aJurusan Fisika, FMIPA, Unsrat, Manado
}

KATA KUNCI

Tsunami, gempa bumi, Bolaang Mongondow

\begin{abstract}
A B S T R A K
Telah dilakukan prakiraan waktu tiba dan tinggi gelombang tsunami guna dalam rangka memperoleh informasi tentang potensi bahaya tsunami di daerah pantai utara Bolaang Mongondow. Data yang digunakan adalah data dari katalog gempabumi USGS periode 1890-2016. Data diolah untuk mendapatkan informasi karakteristik patahan dan dilakukan simulasi gempabumi menggunakan Software WinITDB. Dari hasil simulasi gempabumi, diketahui bahwa daerah pesisir pantai utara Bolaang Mongondow termasuk dalam klasifikasi tsunami yang cukup berbahaya karena tinggi gelombang tsunami yang menerjang adalah $\mathrm{H}>0,5 \mathrm{~m}$ serta energi yang terbangkitkan adalah 2,98 ×1013 joule.
\end{abstract}

KE Y W O R D S

Tsunami, earthquake, Bolaang Mongondow
TERSEDIA ONLINE

01 Agustus 2017

\section{Pendahuluan}

Indonesia merupakan negara kepulauan dengan jumlah pulau lebih dari 17.000 buah dan garis pantai sepanjang $95.181 \mathrm{~km}$. Kondisi ini menyebabkan wilayah Indonesia unggul akan kondisi geografis sehingga menjadi potensi yang besar untuk berbagai kegiatan manusia (Triatmodjo, 1999). Daerah pantai dapat dimanfaatkan sebagai kawasan pusat pemerintahan, pemukiman, industri, pelabuhan, pertambakan, pertanian/perikanan, pariwisata dan sebagainya. Hal ini membuat daerah pantai menjadi daerah yang sangat vital dan bernilai strategis.

Selain memberikan keuntungan bagi masyarakat, keberadaan daerah pantai juga menghadirkan beberapa ancaman, antara lain : angin, erosi, gelombang, arus laut, banjir pasang hingga bencana tsunami. Ditinjau dari segi geologis, Indonesia sangat rentan terhadap gempa dan tsunami karena merupakan daerah pertemuan Lempeng Eurasia, Lempeng Indo-Australia, Lempeng Pasifik, dan Lempeng Laut Filipina (Diposaptono, 2006). Berdasarkan catatan Latief dkk (2000), kejadian tsunami yang pernah terjadi di Indonesia sampai pada tahun 1999 sebanyak 105 kali kejadian tsunami, dimana $90 \%$ terjadi karena gempa tektonik, $9 \%$ oleh letusan gunung berapi, dan $1 \%$ karena tanah longsor.

Wilayah lengan utara Sulawesi merupakan wilayah yang mempunyai tingkat seismisitas yang sangat tinggi (Kertapati, 2006). Penunjaman seperti subduksi Sulawesi Utara (Minahasa Trench), 
tumbukan ganda laut Maluku, penunjaman lempeng laut Filipina, dan beberapa sesar aktif mengakibatkan wilayah ini rawan terhadap gempagempa tektonik (Harmsen, 2007). Gempa terbesar terakhir di lengan utara terjadi pada tahun 1996 dengan magnitudo 7,9 SR (Kertapati, 2006). Gempa ini tergolong berpotensi tsunami yang bisa menimbulkan ancaman serius bagi manusia.

Tsunami merupakan salah satu bencana yang paling ditakuti oleh manusia, karena banyak mengakibatkan kerugian materi dan bahkan menelan ribuan korban jiwa. Pada tahun 2004 tsunami melanda Aceh dan Nias hingga menelan korban jiwa \pm 200.000 orang, tahun 2006 tsunami terjadi di Pangandaran dan menelan 653 korban jiwa serta tahun 2010 tsunami melanda Kepulauan Mentawai dan menelan korban jiwa 456 orang (Syamsidik, 2013).

Bolaang Mongondow merupakan salah satu kabupaten yang ada di provinsi Sulawesi Utara dengan jumlah penduduk 213.484 jiwa dan kepadatan 39,55 jiwa/ $\mathrm{km}^{2}$. Pesisir pantai utara Bolaang Mongondow berbatasan dengan Laut Sulawesi. Kondisi topografi pantai utara Bolaang Mongondow adalah landai.

Informasi gempabumi yang berpotensi tsunami masih kurang bagi masyarakat yang ada di sekitar pesisir pantai utara Bolaang Mongondow. Untuk itu diperlukan informasi yang lebih serta upaya mitigasi bencana tsunami guna mengurangi kerugian dan korban jiwa. Salah satu langkah mitigasi adalah dengan melakukan studi tentang tingkat resiko tsunami seperti waktu tiba dan tinggi gelombang tsunami yang menerjang lengan utara pulau Sulawesi khususnya di pesisir pantai utara Bolaang Mongondow. Kajian serupa di pesisir pantai utara Bolaang Mongondow sudah pernah dilakukan oleh Pandey (2015), namun hanya menggunakan sumber pembangkit yang jauh, padahal di dekat pesisir pantai utara Bolaang Mongondow terdapat patahan yang berpotensi menghasilkan gempa seperti patahan darat Bolaang Mongondow (patahan naik/turun). Oleh karena itu, dalam penelitian ini telah dilakukan studi tentang potensi tsunami dengan sumber pembangkit adalah patahan yang jaraknya relatif dekat dengan pesisir pantai utara Bolaang Mongondow.'

Penelitian dilakukan dengan memanfaatkan software WinITDB untuk melakukan simulasi. Dari simulasi tersebut telah diketahui waktu tiba tsunami menerjang pantai serta ketinggian gelombang tsunami. Selain itu telah dilakukan juga perhitungan tentang besar energi tsunami.

\section{Material dan Metode}

Penelitian dilakukan dengan memanfaatkan software WinITDB. Sumber data gempabumi yang digunakan adalah dari USGS periode 1890-2016. Batas wilayah yang diteliti adalah wilayah yang berada dipesisir pantai utara Bolaang Mongondow $\left(0^{\circ} \mathrm{LU}-1^{\circ} \mathrm{LU}\right)$ dan $\left(123^{\circ} \mathrm{BT}-124^{\circ} \mathrm{BT}\right)$.
Penelitian diawali dengan memilih lokasi yang padat penduduk, kemudian diplot sebagai titik yang akan diterjang tsunami. Selanjutnya menginput data historis dari USGS. Kemudian melakukan perhitungan manual panjang patahan, lebar patahan, dan deformasi dasar laut. Menginput posisi lintang sumber tsunami, posisi bujur sumber tsunami, posisi lintang daerah yang akan diterjang tsunami, posisi bujur daerah yang akan diterjang tsunami, panjang patahan, lebar patahan, deformasi dasar laut, dan waktu maksimum penjalaran gelombang tsunami untuk melakukan simulasi dengan software guna mendapatkan waktu tiba dan tinggi gelombang tsunami.

\section{Hasil dan Pembahasan}

Kasus tsunami I terjadi pada tanggal 05 Januari 1941 yang disebabkan oleh gempabumi dengan magnitude 6,7 Mw terletak pada koordinat 0,70 - $2^{0}$ LU dan 121,50 - 124,60 BT (Gambar 3.1). Ketika terjadi gempabumi dengan magnitudo 6,7 Mw, maka panjang patahan yaitu $21,88 \mathrm{~km}$, lebar patahan yaitu $16,03 \mathrm{~km}$, dan deformasi dasar laut yaitu 0,59 meter. Jarak dari sumber tsunami ke lokasi reka ulang yaitu $32,82 \mathrm{~km}$. Besar energi yang terbangkitkan akibat gelombang tsunami pada kasus pertama adalah $6,15 \times 10^{11}$ joule dengan kategori yang tidak membahayakan serta tinggi maksimum gelombang tsunami yang terjadi 1,43 meter di desa Bolontio. Gambar 3.2 menunjukkan bahwa tinggi gelombang tsunami yang menerjang lokasi reka ulang adalah 0,1 meter pada menit ke22, dan masih tergolong dalam klasifikasi tsunami yang tidak berbahaya.

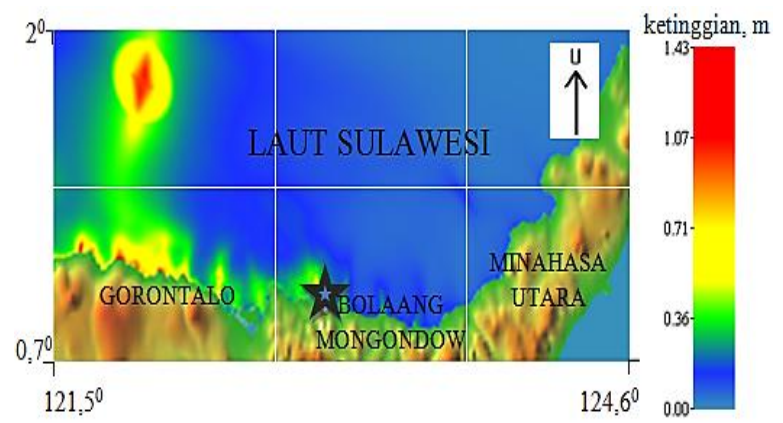

Gambar 3.1 Hasil simulasi penjalaran tsunami dari pusat gempabumi dengan magnitudo 6,7 Mw. Keterangan:

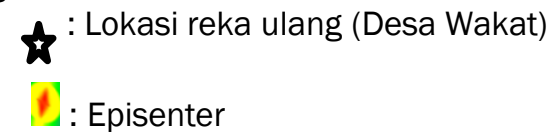




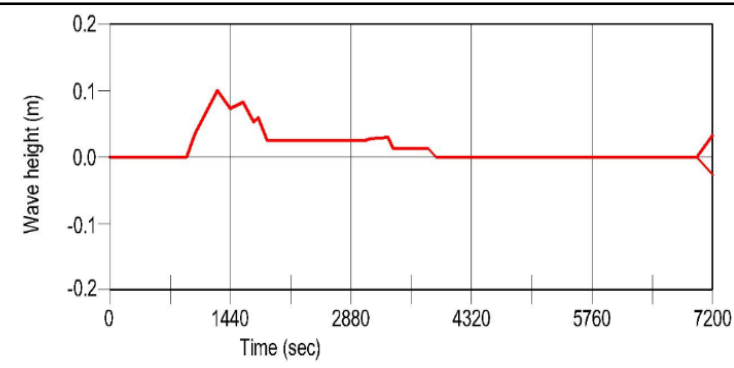

Gambar 3.2 Grafik waktu tiba dan tinggi gelombang tsunami dari pusat gempabumi dengan magnitudo 6,7 Mw.

Kasus tsunami II pada tanggal 20 Juni 1991 yang disebabkan oleh gempabumi dengan magnitudo 7,5 Mw terletak pada koordinat 0,70 - $2^{0}$ LU dan 121,50 - 124,60 BT (Gambar 3.3). Pada saat terjadi gempabumi dengan magnitude 7,5 Mw, maka panjang patahan yaitu $54,95 \mathrm{~km}$, lebar patahan yaitu $30,55 \mathrm{~km}$, dan deformasi dasar laut yaitu 1,88 meter. Jarak dari sumber tsunami ke lokasi reka ulang yaitu 82,43 km. Besar energi yang terbangkitkan akibat gelombang tsunami pada kasus kedua yaitu 2,98 $\times 10^{13}$ joule dengan kategori cukup berbahaya serta tinggi maksimum gelombang tsunami yang terjadi adalah 5,81 meter di desa Monano. Tinggi gelombang tsunami yang menerjang lokasi reka ulang (Desa Ambang) adalah 0,8 meter pada menit ke-17 (Gambar 3.4). Hal ini menunjukkan bahwa potensi tsunami di daerah tersebut tergolong dalam kategori tsunami yang cukup membahayakan. Adapun data waktu tiba dan tinggi gelombang tsunami pada dua daerah dapat dilihat pada Tabel 1.1 .

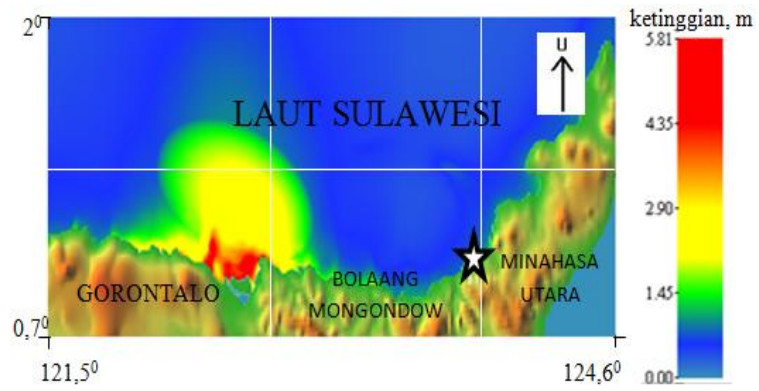

Gambar 3.3 Hasil simulasi penjalaran tsunami dari pusat gempabumi dengan magnitudo 7,5 Mw.

Keterangan:

$$
\begin{aligned}
& \boldsymbol{t}^{\text {: Lokasi reka ulang (Desa Ambang) }} \\
& \quad \text { : Episenter }
\end{aligned}
$$

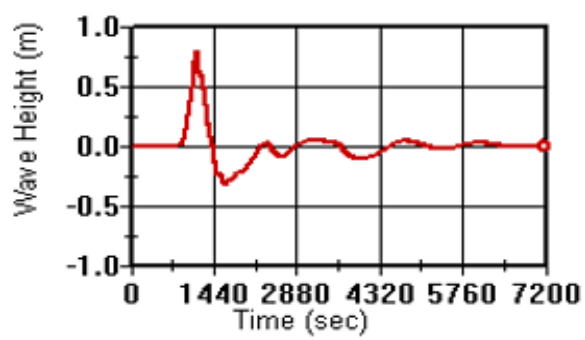

Gambar 3.4 Grafik waktu tiba dan tinggi gelombang tsunami dari pusat gempabumi dengan magnitudo

$$
\text { 7,5 Mw. }
$$

Tabel 1.1 Data waktu tiba dan tinggi maksimum gelombang tsunami yang disebabkan oleh kasus tsunami II

\begin{tabular}{|c|c|c|c|c|c|}
\hline No & $\begin{array}{c}\text { Sumber } \\
\text { Gempabumi }\end{array}$ & $\begin{array}{c}\text { Magnitudo } \\
\text { (Mw) }\end{array}$ & $\begin{array}{c}\text { Wilayah } \\
\text { Pesisir }\end{array}$ & $\begin{array}{c}\text { Waktu Tiba } \\
\text { Tsunami } \\
\text { (menit) }\end{array}$ & $\begin{array}{c}\text { Tinggi } \\
\text { Gelombang } \\
\text { Maksimum } \\
\text { (meter) }\end{array}$ \\
\hline 1 & $\begin{array}{c}1,63 \mathrm{LU} \\
122,22 \mathrm{BT}\end{array}$ & 6,7 & Ambang & 24 & 0,06 \\
\cline { 1 - 4 } & & Wakat & 22 & 0,1 \\
\hline 3 & $\begin{array}{c}1,20 \mathrm{LU} \\
122,79 \mathrm{BT}\end{array}$ & 7,5 & Ambang & 17 & 0,8 \\
\cline { 1 - 1 } & & Wakat & 19 & 0,51 \\
\hline
\end{tabular}

4. Kesimpulan

1. Besar energi yang terbangkitkan akibat gelombang tsunami dengan episenter di laut dari tahun 1890 - 2016 pada kedalaman $<100 \mathrm{~km}$ dan magnitudo >6,5 Mw di daerah pesisir pantai utara Bolaang Mongondow adalah $2,98 \times 10^{13}$ joule.

2. Waktu tiba minimum gelombang tsunami di pesisir pantai utara Bolaang Mongondow adalah 17 menit di desa Ambang. Sedangkan waktu tiba maksimum 24 menit setelah kejadian gempa.

3. Tinggi maksimum gelombang tsunami adalah 0,8 meter.

\section{Daftar Pustaka}

Diposaptono, S., dan Budiman. 2006. Tsunami. Buku IImiah Populer. Bogor.

Kertapati, E.K. 2006. Aktivitas Gempabumi di Indonesia. Pusat Survei Geologi, Bandung. 6467.

Latief, H., Puspito, N.T. dan F. Imamura. 2000. Tsunami catalog and zones in Indonesia. Journal of Natural Disaster Science. 22(1): 2543.

Pandey, F. 2015. Simulasi Penjalaran Tsunami di Beberapa Pantai di Sulawesi Utara sebagai Upaya Mitigasi Bencana.[Skripsi]. FMIPA UNSRAT, Manado.

S. Harmsen. 2007. USGS Software For Probabilistic Seismic Hazard Analysis (PSHA), United Statesof Geological Surveys (USGS).

Syamsidik., Hassanuddin., M. Dirhamsyah., K. Munadi. 2013. Analisis Pendahuluan Penanggulangan Bencana Tsunami Indonesia.Prosiding Seminar Nasional Riset Kebencanaan; Mataram 8-10 Oktober 2013.

Triatmodjo, B., 1999. Teknik Pantai. Yogyakarta: Beta Offset 